\title{
DIVERSIDADE DE ÁCAROS PLANTÍCOLAS ASSOCIADOS A SISTEMAS AGROFLORESTAIS E PLANTAS NATIVAS NO SUL DA BAHIA
}

\author{
AUTOR: LAIZA MIRELLE SANTOS ANDRADE \\ CO-AUTOR/ORIENTADOR: FELIPE MICALI NUVOLONI
}

\begin{abstract}
Resumo: Existem poucos estudos sobre a influência dos ecossistemas em sistemas agroflorestais, apesar de haver uma importante relação entre a diversidade de espécies e os serviços ambientais prestados. O presente trabalho buscou verificar a possível influência de fragmentos da Mata Atlântica sobre a distribuição e ocorrência das espécies de ácaros em sistemas agroflorestais. O estudo foi realizado em um sistema agroflorestal com cultivos de açaí e cupuaçu consorciados na Fazenda Bom Sossego no município de Porto Seguro (BA). As amostragens tiveram frequência mensal pelo período de seis meses (setembro de 2019 a fevereiro de 2020), utilizando três transectos que distanciaram do fragmento de vegetação nativa (10, 30 e 50 metros). Foram selecionadas e amostradas mensalmente cinco plantas de açaí e cupuaçu por transecto. No total foram encontrados 5.892 ácaros de 33 espécies, pertencentes a 15 famílias. As análises da distribuição dos ácaros predadores e fitófagos indicou que não houve diferença na abundância entre os transectos no geral, entretanto foram observadas diferenças quanto às espécies e ao período de ocorrência, sendo que os predadores tiveram uma correlação positiva com a temperatura, pressão e umidade e os fitófagos com temperatura e umidade com picos de abundância em fevereiro. A composição de espécies não diferiu entre os transectos, mas sim entre os hospedeiros e o período de coleta. A riqueza de espécies entre os hospedeiros e transectos não teve diferenciação, apesar de haver uma tendência de haver maior número de espécies próximas à borda da mata. Registramos pela primeira vez a ocorrência de danos em açaí pelo ácaro Raoiella indica que ocorreu em elevada abundância, no transecto mais distante da borda, além de uma associação positiva com o fitoseídeo Amblyseius operculatus.
\end{abstract}

Palavras-chave: Ácaro, controle biológico, efeito de borda, sistemas agroflorestais. 